\title{
STŘEDOVĚKÉ USŇOVÉ OPASKY V ARCHEOLOGICKÝCH NÁLEZECH
}

\author{
ALEŠ HOCH
}

\begin{abstract}
Abstrakt: Přispěvek se zabývá problematikou středověkých usňových opasků nalezených při archeologických výzkumech na územi České republiky. Počtem nevelká nálezová kolekce čitající osmnáct artefaktů byla vybrána z vice než čtyřiceti lokalit a tisíců dalšich usňových předmétů datovaných do rozmezi 13. až počátek 16. století. Soubor by rozdělen do skupin na základě výzdoby, což se vzhledem k značné fragmentárnosti nálezů prozatím jeví jako nejlepši možnost. Rozlišeno bylo celkem pět základních výzdobných skupin, mezi kterými maji nejpočetnějši zastoupeni opasky zdobené liniemi drobných prosekávaných otvorů. $K$ dalšim zjištěným způsobům výzdoby patři kovové aplikace, obšivání, barvení a ražba.
\end{abstract}

Klíčová slova: vrcholný a pozdni středověk-opasky-usně-móda.

\section{Medieval leather belts among archaeological finds}

Abstract: This paper discusses the issue of medieval leather belts found during archaeological excavations in the Czech Republic. The small series of eighteen artefacts was selected from more than forty sites and thousands of other leather objects spanning the 13th and the early 16th century. The series was divided into groups on the basis of decoration, which seems the best option, given the fragmentary nature of the finds. Five basic decoration groups were defined, among which belts decorated with rows of small cut holes make up the largest one. Other manners of decoration identified include metal appliqués, sewing, dyeing and embossing.

Key words: high and late Middle Ages - belts - leather - fashion.

\section{1 Úvod}

Opasky, nazývané v dobových pramenech pásy, byly běžnou součástí středověkého oděvu. Nosily se opasky od jednoduchých variant v podobě provazů po extrémně nákladné, vyrobené z hedvábí a drahých kovů. Jejich role se ovšem neomezovala pouze na funkční oděvní doplněk sloužící zároveň jako nepostradatelný závěsný systém pro nošení předmětů denní potřeby. Opasky měly pro středověkého člověka podstatnou roli také v symbolické rovině a odkazovaly na společenské a sociální postavení svého majitele (Šlancarová 2018, 142). Pás mohl být samostatným šperkem, prostředkem středověké neverbální komunikace, nástrojem k naplnění právního aktu či ukazatelem stigmatu (např. prostituce). Absence opasku, připnutí či odepnutí, barva a jiné faktory byly signifikantní pro stav a konání jeho majitele. V literární podobě si z dávných dob uchoval i magické a apotropaické schopnosti (Mazáčová 2012, 6, 20).

Význam opasku jako celku nebyl doposud v našem badatelském prostředí, až na výjimky, plně reflektován. Pozornost byla věnována hlavně jeho kovovým komponentům, jako jsou přezky a nákončí, případně ozdobné aplikace (Procházka 1990; Macháňová 2007; Zůbek 2002; Šlancarová 2016; 2018 aj.). Středověký opasek byl ovšem nositelem - obdobně jako jeho profesionální výrobci zvaní pasíři - mnohovrstevného významu. Vyráběl se z vyčiněných kůží, textilu či kovu a kovové byly nejčastěji i jeho další součásti. ${ }^{1}$ Minimálně přezky však byly vyráběny i z kosti a parohu. Na opasková kování se tak dá pohlížet optikou šperku, a jsou proto řazena i do této kategorie hmotné kultury (srov. Šlancarová 2016; 2018). Prozatím jedinou prací pocházející z našeho badatelského prostředí a nahlížející problematiku opasků optikou vícero pramenů je diplomová práce a z ní vycházející publikace P. Mazáčové (2012). Dílna pasíře s opasky a dalšími komponenty z přelomu 15. a 16. století byla archeologicky doložena v Táboře (Krajíc 1998). V zahraničí se této problematice intenzivně věnovala zejména německá badatelka I. Fingerlin (napřs. 1977) či nověji C. Schopphoff (2009). Samostatnou kapitolu o opascích najdeme např́iklad v publikacích

1 Více k pasířskému řemeslu Krajíc 1998. 
zabývajících se usňovými nálezy ze Šlesviku (Schnack 1998, 44-58), Londýna (Egan-Pritchard 2002, 19-246), Yorku (Mould-Carlisle-Cameron 2003, 3392-3401) a Štětína (Kowalska 2010, 113-115; 2013, 173-184) či v dílčích studiích a článcích (např. Wywrot-Wyszkowska-Janowski 2017; Lawrynowicz 2005).

\section{Středověký opasek - stručná charakteristika}

Jak již bylo řečeno v úvodu, opasek byl důležitým doplňkem středověkého oděvu. Zmínky o opascích, resp. pásech (lat. cingulum), proto najdeme i v dobových písemných pramenech. Pro svou zdobnost, a tedy i vyšší materiální hodnotu se nezř́ídka stávaly součástí testamentů. ${ }^{2}$ Pokud však není výslovně uveden materiál, ze kterého je pás vyroben, není možné určit, zda se jedná o výrobek z usně, textilu či kovu. Obdobný problém vyvstává i při studiu ikonografických pramenů, které jsou jinak výborným a bohatým zdrojem informací. Je nutné mít na paměti, že v prípadě schematického zobrazování, bez přítomnosti markantních detailů, může být obtížné rozlišit usňové pásy od textilních (obr. 1). V písemných pramenech jsou také často zmiňovány pásy stříbrné či pozlacené, čímž měli doboví autoři na mysli

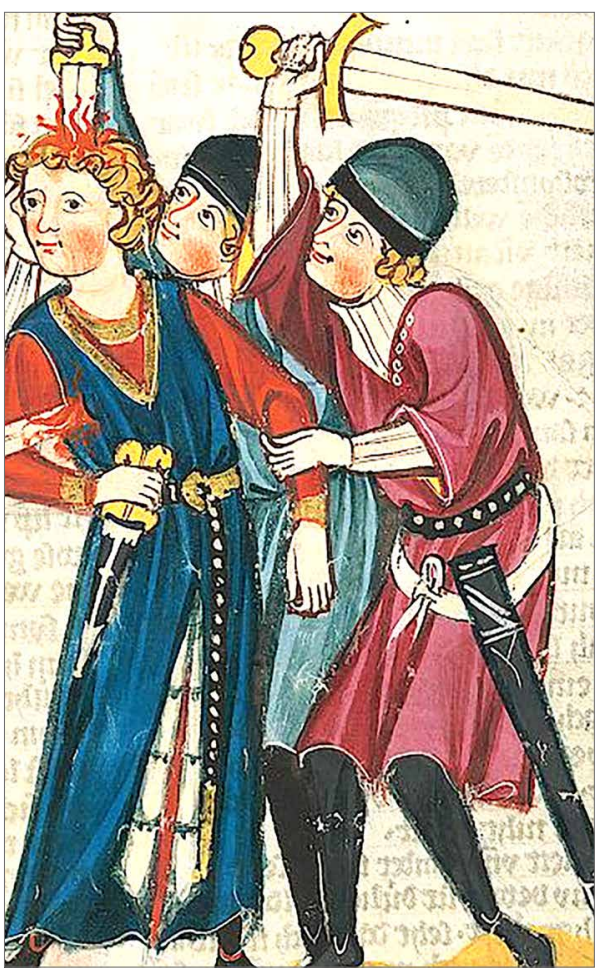

Obr. 1. Př́íklad ikonografického pramene (Codex Manesse, počátek 14. století) s dobře odlišitelnými pásy: bílý textilní, sloužící k zavěšení meče a černý usňový s metalickými aplikacemi. Podle Walther-Siebert 1992, upraveno.

Abb. 1. Beispiel einer ikonographischen Quelle (Codex Manesse, Anfang 14. Jahrhundert) mit gut unterscheidbaren Gürteln: weißer Textilgürtel zum Einhängen eines Schwertes und ein schwarzer Ledergürtel mit Metallapplikationen. Nach Walther-Siebert 1992, bearbeitet. primárně jejich kovové komponenty. Přílišná až přehnaná zdobnost vyvolávala i snahu o regulaci, zejména ze strany městských samospráv a bývala trnem v oku i dobovým mravokárcům.

S opasky bývají zmiňovány i předměty, které se na ně běžně zavěšovaly - zbraně, nože, tobolky, tašky, měšce, klíče, pouzdra apod. (Zíbrt 1892, 343; Mazáčová 2012, 36). Nepostradatelnou úlohu měly opasky během aktu pasování, v jehož názvu se i přímo odráží (obr. 2). Během tohoto slavnostního rituálu

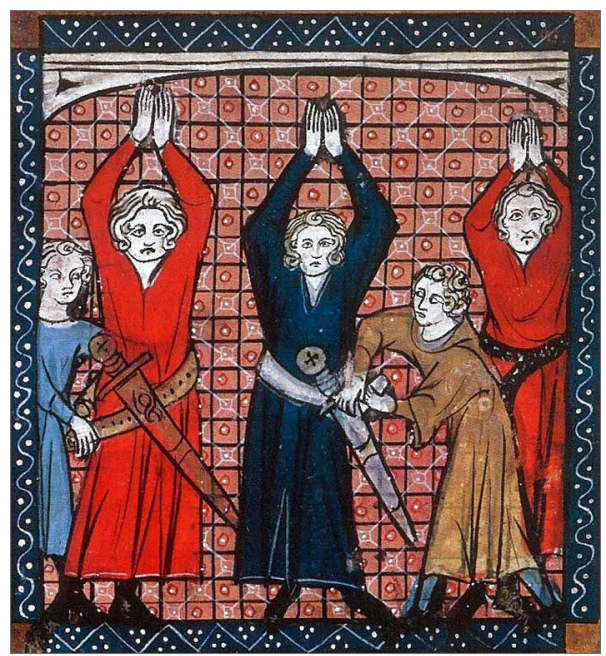

Obr. 2. Akt pasování na rytíře, francouzská iluminace ze 13. století. Podle Flori 2008.

Abb. 2. Akt des Ritterschlags, französische Illumination aus dem 13. Jahrhundert. Nach Flori 2008. 
byly rytíŕi předány tř́i základní insignie jeho nového postavení, a to meč, ostruhy a opasek (lat. cingulum militare, cingulum insignie; více k tématu pasování napr. Zelenka 2012; Iwańczak 2000; Flori 2003; Mazáčová 2012, 9-18). Tyto opasky, označované také jako rytířské či mečové, tak vytváŕí vlastní specifickou skupinu, která je ovšem v archeologických nálezech obtížně rozpoznatelná (srov. Wywrot-Wyszkowska-Janowski 2017; Mazáčová 2012, 37-38; Lawrynowicz 2005). Specifickou symboliku měly opasky také ve spojení s liturgickými oděvy a mnišstvím (více Mazáčová 2012, 25-27). Opasky neboli pásy nosili bez rozdílu muži i ženy, přičemž podobu a způsob nošení ovlivňovala dobová móda. ${ }^{3}$ Značně oblíbeny byly od 14 . století úzké, prodloužené varianty (tzv. dlouhé pásy), provlékané za pasem do uzlu, s koncem ponechaným volně spuštěným k zemi (obr. 3). Tento typ, dlouhý i více než $150 \mathrm{~cm}$, nosili muži i ženy, přičemž delší varianty jsou častěji ke spatření u žen (Wywrot-Wyszkowska-Janowski 2017, 218). Jiné typy byly

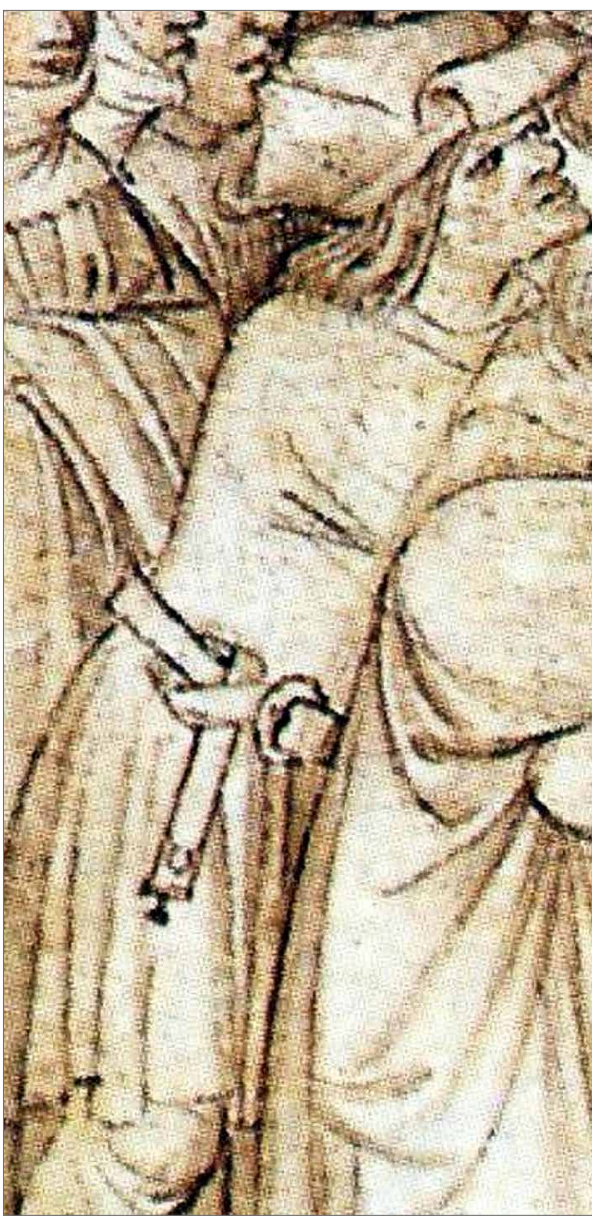

Obr. 3. Opasek provlečený do uzlu. Výjev z cest Johna de Mandeville (výŕez), počátek 15. století. Podle Krása 1990, 283, upraveno.

Abb. 3. zu einem Knoten gebundener Gürtel. Szene aus den Reisen des Jean de Mandeville (Ausschnitt), Anfang 15. Jahrhundert. Nach Krása 1990, 283. bearbeitet.

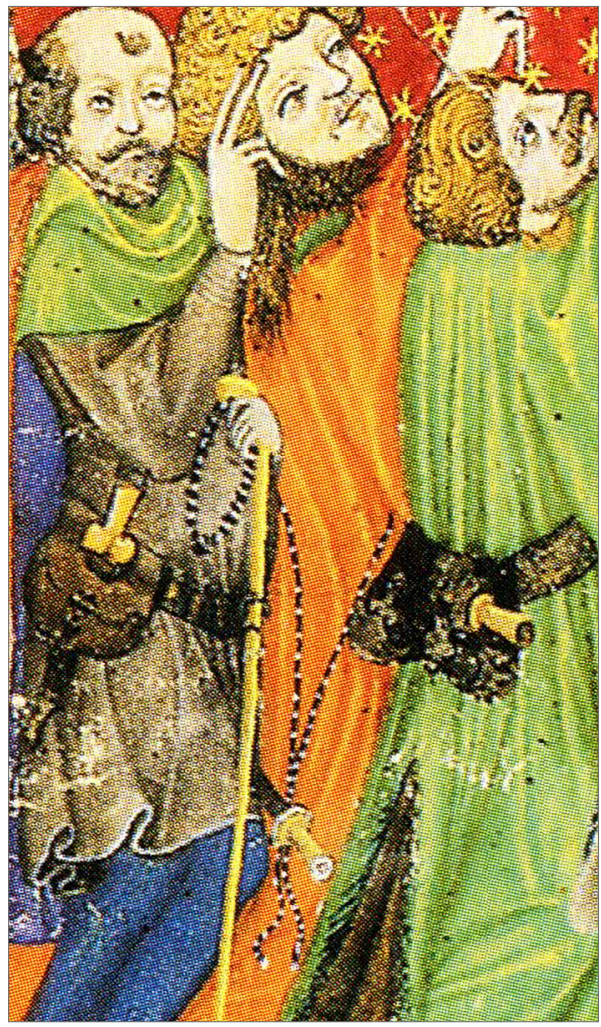

Obr. 4. Př́ísaha jihlavské městské rady, Gelnhausenův kodex. Na iluminaci vzniklé v prvním desetiletí po roce 1400 má prostřední postava dobře patrný dlouhý úzký pás / řemen s dýkou, zavěšený přes hrud'. Oba krajní konšelé mají široké varianty klasických pásů zdobené kovovými aplikacemi. Podle Brodský 2012, 214, upraveno.

Abb. 4. Eid eines Iglauer Stadtrats, Codex Gelnhausen. Auf der im ersten Jahrzehnt nach 1400 entstandenen Illumination hat die mittlere Figur einen gut sichtbaren, langen schmalen über die Brust gehängten Gurt / Riemen mit Dolch. Beide Schöffen am Rand haben breite Varianten von klassischen mit Metallapplikationen verzierte Gurte. Nach Brodský 2012, 214, bearbeitet.

3 Minimálně dle testamentů se zdá, že mohly být i rozlišovány na mužské a ženské (viz Mazáčová 2012, 23). 
nošeny volně pod přirozeným pasem (široký kyčelní pás oblíbený ve 14. století), nebo naopak stažené nad boky a zvýrazňující linii pasu (rámcově 15. století). Od 15. století přichází do módy i celokovové opasky (Pilná 2018, 46). Po husitských válkách nastupuje móda zvýšeného pasu zvýrazněného právě opaskem. Na pomezí opasků a řemenů zřejmě oscilovaly extrémně úzké a dlouhé varianty, zavěšené šikmo přes rameno a prsa (běžně ve spojení s dýkou), se kterými jsou v ikonografických pramenech 15. století vyobrazování zejména muži (obr. 4; Kybalová 2001, 200; Mazáčová 2012, 36-43; Šlancarová 2018, 142-150). Rozlišovány tak byly pásy usňové, textilní či kovové, úzké, široké, dlouhé, krátké, barvené, zdobené, prosté, zapínané pomocí přezek, háčků a zápon.

\section{Typologie a problematika určování}

Nálezy nejen usňových opasků, zvláště těch nákladně provedených, nejsou v našem archeologickém prostředí př́liš časté. Předkládaná kolekce byla vybrána z více než sedmi tisíc artefaktů ze čtyřiceti lokalit (viz Hoch 2020, 51-56). Tato skutečnost má dvě roviny: historickou a př́rodní. Historické hledisko bylo již nastíněno v předchozí stati. Zdobné a honosné pásy byly považovány za hodnotný majetek, odraz společenského postavení nositele a bývaly součástí dědických řízení. Lze proto důvodně předpokládat, že byly opečovávány, v případě poškození opravovány a střeženy. Pokud již došlo k jejich vyhození z důvodu nepotřeby, byla z nich drahá kování odstraněna. Druhou př́íčinou jejich nízkého výskytu mezi archeologickými nálezy jsou př́rodní procesy. Opasky byly vyráběny jak z trrísločiněných usní, které dokážou odolávat hnilobným a rozkladným procesům, tak z ostatních typů usní (zejména jirchy), které již rozkladu podléhají. Z textilu vydrží deponování v půdě většinou pouze materiál živočišného původu (vlna, hedvábí, plst'), nikoliv rostlinná vlákna. Důvod obliby usní, které nebyly vyčiněny trríslem, a textilu je nasnadě. Jde o materiály dobře barvitelné permanentními barvami, ${ }^{4}$ na rozdíl od tř́ísločiněné usně, kterou přírodní barviva př́liš neobarví, a proto musí být dekorována jinak. Tímto se dostáváme k základní typologii opasků - lze je rozdělit podle materiálu na usňové, textilní a kovové (př́ípadně kombinované). Možné, ačkoliv interpretačně značně obtížné je i dělení z hlediska módy a funkce (napřr. rytířské, měštanské, liturgické aj.). Z pohledu archeologie bývají rozlišovány zejména dle tvaru a způsobu konstrukce (jednoduché, zdvojené, přehýbané, přehýbané s vloženým páskem apod.; srov. Schnack 1998, 46). Tento postup ovšem není v našem prostředí uplatnitelný z důvodu malého počtu nálezů a jejich značné fragmentárnosti. Navíc technika výroby zahrnující zdvojení či přehnutí (a následné sešití, prřípadně nýtování) materiálu je $\mathrm{v}$ našem prostředí doložena sporadicky a prozatím se zdá, že zde neměla

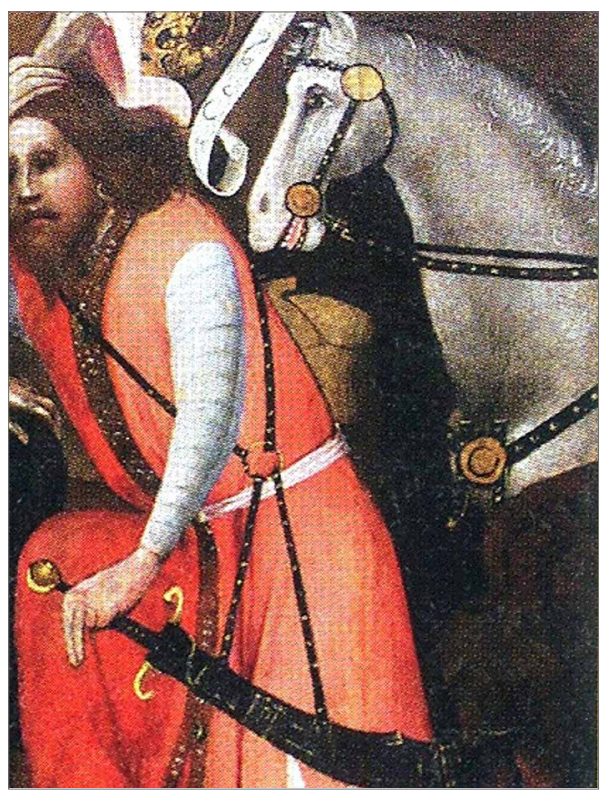

Obr. 5. Výřez z obrazu Karel Veliký se zpovídá sv. Egidiovi (kolem 1425) ukazuje identické provedení závěsu pochvy panovníkovi zbraně a koňského postroje. Podle Šlancarová 2018, 204, obr. 92, upraveno.

Abb. 5. Der Ausschnitt aus dem Bild Karl der Große im Beichtgespräch mit dem heiligen Ägidius (um 1425) zeigt eine identische Ausführung des Scheidengehänges für die Waffe des Herrschers und des Pferdegeschirrs. Nach Šlancarová 2018, 204, Abb. 92, bearbeitet. 
tradici. ${ }^{5}$ Kompletně dochovaný opasek, tedy se všemi nezbytnými kováními, měřitelný v celé délce a šířce, nebyl zastoupen v žádném ze sledovaných souborů a velice vzácný je i v zahraničních nálezech (srov. Wywrot-Wyszkowska-Janowski 2017). Nálezům tak dominují větší či menší fragmenty, zcela výjimečně i s dochovanými přezkami či ozdobnými aplikacemi, nebo alespoň s prokazatelnými stopami (negativy) po jejich dřívěšsí přítomnosti. Jako jediný možný způsob se tak prozatím jeví rozdělení do skupin podle způsobu výzdoby, a to na opasky základní zdobené a nezdobené. U obou kategorií také platí, že je často obtížné rozlišit opasek od jiných tvarově podobných předmětů, jako jsou řemeny a popruhy (např. z koňských postrojů, závěsů pro pobočné zbraně, psích obojků, ostruh, tašek a tobolek, pochev na nože apod.; obr. 5).

\subsection{Zdobené opasky}

Způsoby zdobení předmětů, které byly ve sledovaných souborech určeny jako možné opasky, jsou různé. Identifikovat se podařilo pět základních typů, které se v rámci skupiny lišily jen v detailech. Možná byla také kombinace vícero výzdobných prvků. Jedná se konkrétně o prosekávání / prošivání, ražbu / rytí / lisování, obšiváni okrajủ, zdobení metalickými aplikacemi a polychromii.

Prosekávání (kat. č. 1-11; tab. I až 3), na které velice pravděpodobně navazovalo téměř vždy ještě prošivání (obr. 6), je jednoznačně nejrozšířenější a nejčastěji zastoupenou formou zdobení identifikovanou ve sledovaných souborech. ${ }^{6}$ Výskyt takto upravovaných opasků (případně řemenů) je natolik pravidelný, že je lze klasifikovat a vyčlenit jako samostatný typ, označitelný za prosekávaný / prošivaný opasek. Takové byly objeveny v souborech z Brna, Litovle, Veselí nad Moravou, Uherského Hradiště, Českých Budějovic, Cvilínku u Pelhřimova a Hradce Králové (tab. I až III). Způsob základního provedení byl u všech podobný a lišil se pouze ztvárněním zdobného motivu. Do pruhu vykrojené usně, nejčastěji identifikované jako hovězina, byly pomocí úzkého ostrého hrotu (nůž, průbojník s plochým hrotem) prosekány 1 až $3 \mathrm{~mm}$ dlouhé, protáhlé (případně oválné), na husto kladené otvory (rozestupy $\mathrm{v}$ řádu $\mathrm{mm}$ ), procházející skrz celý materiál. Až na jedinou výjimku (u které navíc není jisté, zda pochází z opasku) byly tyto otvory ukládány podél obou delších okrajů, a to bud' šikmo (nejběžněji), svisle či vodorovně (méně časté). Takováto linie byla zhotovena bud'to jedna, nebo dvě jdoucí paralelně vedle sebe. V nadpoloviční většině pak byly opasky zdobeny stejnou technikou také ve svém středu. Zde se však zvolený motiv výrazně lišil předmět od předmětu. V nejjednodušší variantě byla přidána jedna až dvě řady otvorů kladených obdobným způsobem jako při okrajích. U složitějších variant pak byly do těchto linií
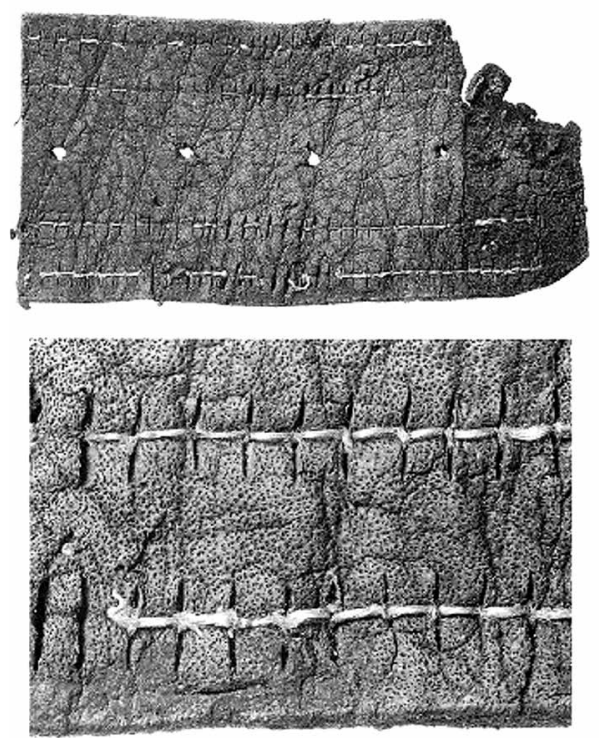

Obr. 6. Prosekávané a zároveň prošívané opasky z Londýna. K prošití bylo použito hedvábí. Podle Egan-Pritchard 2002, 38 , obr. 21, upraveno.

Abb. 6. Gestanzte und gleichzeitig gesteppte Gürtel aus London. Für die Steppung wurde Seide verwendet. Nach Egan-Pritchard 2002, 38, Abb. 21, bearbeitet.

5 Tento fakt může být pouze odrazem stavu výzkumů. Na druhé straně byl již zpracován dostatečně reprezentativní počet souborů, aby tato skutečnost nemohla být pouhou náhodou. Problémem při přesném určení se tak opět stává zejména fragmentárnost, kdy je obtižné odlišit například překládané opasky od pochev (srov. Schnack 1998, 49).

6 Řady drobných prosekávaných otvorů se vyskytuji i na zcela jiných výrobcích, např́íklad po stranách měšců či na vnitřních dílcích tašek a tobolek. V př́padě dostatečně velkých částí není problém od sebe tyto artefakty odlišit, opatrnost při určování je však na místě u velmi malých fragmentů. 
přidávány v pravidelném rozestupu další motivy (kolečka, vlnovky, klikatky aj.). V nejsložitější variantě se pak středový motiv průběžně měnil (klikatil, kroutil, větvil). Otvory mohly být následně ještě prošívány nití, velmi pravděpodobně barevně odlišnou (obr. 7). V našem prostředí se takové prošití nedochovalo, jelikož k němu byla zřejmě používána šicí nit' rostlinného původu, známe ho však ze zahraničí (napřs. Londýna), odkud je doloženo prošití hedvábím (viz obr. 6). Takovéto prošití mělo nejen dekorační funkci, ale zároveň zabraňovalo natahování materiálu (Mould-Carlisle-Cameron 2003, 3392-3397; Egan-Pritchard 2002, 38-39). V Anglii tyto opasky proto také neoznačují jako ,prosekávané“, ale „prošívané“. Několik takto zdobených usňových pásů je zde interpretováno i jako součást koňského postroje, konkrétně uzdy. S anglickými nálezy se naše shodují i v použitém materiálu, kterým byla ve většině určitelných případů hovězina. Téměř shodné je také jejich hlavní časové zařazení, a to do rozmezí 12. až 13. století pro York a pozdního 12. až 14. století pro Londýn (Mould-Carlisle-Cameron 2003, 3392-3393). Do 13. až 14. století jsou datovány také obdobně zdobené opasky z německého Šlesviku (Schnack 1998, 55). Nálezy z našeho prostředí prozatím spadají do časového rozpětí druhé poloviny 13. století až druhé poloviny 14. století. Se zmíněnými lokalitami koresponduje i šiřka opasků nalezených na našem území, která oscilovala mezi 14 až $47 \mathrm{~mm}$, přičemž největší počet exemplářủ se pohyboval v rozmezí 20 až $25 \mathrm{~mm}$. V anglickém Yorku rozměr obdobně zdobených opasků a řemenů osciloval mezi 11 až 46 mm a v německém Šlesviku průměrně mezi 24 až 36 mm (Schnack 1998, 57). Ze zahraničí jsou dále známy např́íklad z Kostnice (Schnack 1994, Taf. 43), Kolobřehu (Wywrot-Wyszkowska 2008, 206), Štětína (Kowalska 2013, 228-229) a mnoha dalších lokalit. Zajímavý může být i fakt, že jsou nacházeny v různých sociokulturních prostředích (město, předměstí, předhradí hradu, hornický areál). Nebudeme zřejmě daleko od pravdy, prohlásíme-li tento typ opasků za hojně rozšířený a oblíbený (dostupný) především u běžné populace.

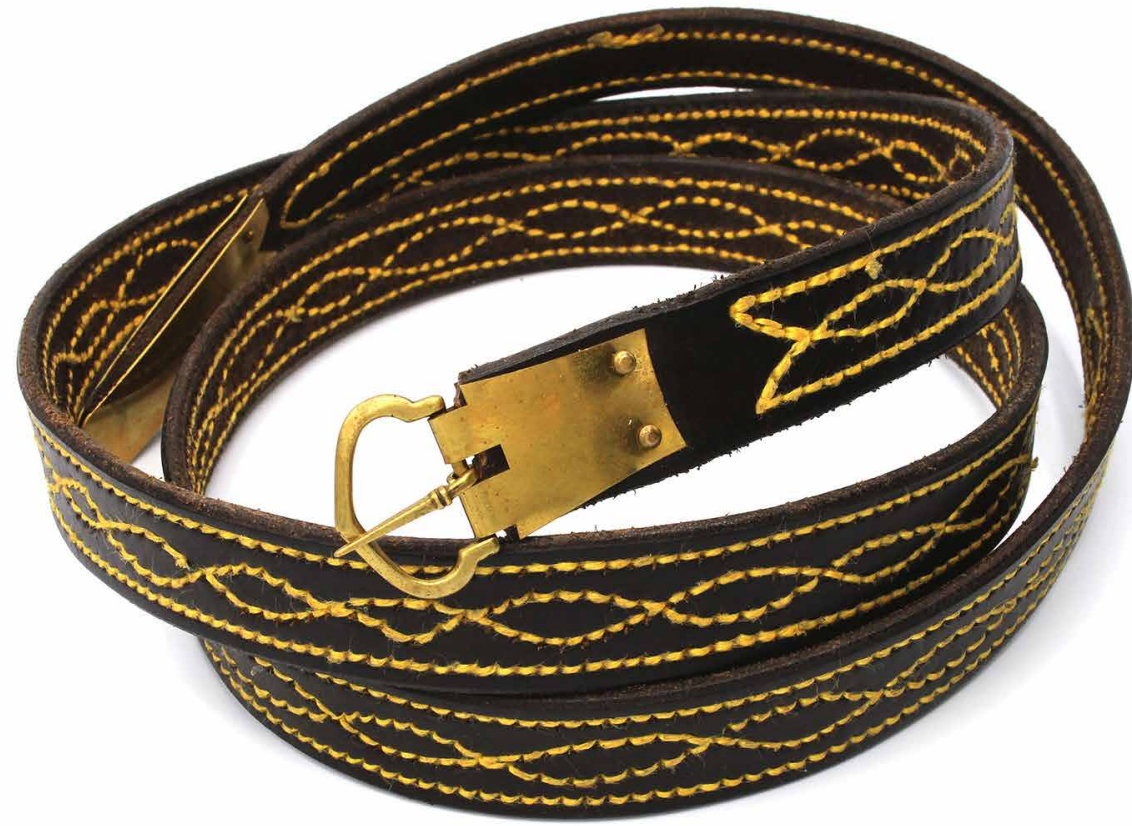

Obr. 7. Ukázka repliky prošívaného opasku. Autorka Jana Skalská Obročníková; zdroj www.dobraczech.cz.

Abb. 7. Beispiel einer Replik eines gesteppten Gürtels. Autorin Jana Skalská Obročníková; Quelle www.dobraczech.cz. 
Zdobení metalickými aplikacemi (kat. č. 12-14; tab. IV) je výzdobný styl nastoupivší v průběhu 13. století s vrcholem oblíbenosti ve 14. století. Doložen je ve dvou případech přímo (Veselí nad Moravou, Jihlava) a v jednom nepř́mo (Hradec Králové). Mimo sledované soubory byl opasek s dochovanými kovovými aplikacemi nalezen např́íklad v Praze (Figura 2019, 30) nebo Čáslavi (Frolík a kol. 1999). Kovové aplikace (označované zjednodušeně také jako tzv. kování) měly bohatou škálu podob a tvarů a variabilní byl také použitý materiál (nejčastěji slitiny mědi a slitiny olova a cínu). Pokud je takové „kování“ nalezeno samostatně (a takových nálezů je drtivá většina), je často problematické určit, zda jde o ozdobu z opasku, př́ípadně koňského postroje, tašky či tobolky, měšce nebo i knihy. Přehled základní literatury ke kovovým aplikacím je uveden $\mathrm{v}$ úvodu textu.

Polychromie (kat. č. 15; tab. IV) je poslední z doložených výzdobných motivů. Jedná se vcelku o unikátní doklad snahy o barvení, tj. vylepšení vzhledu třísločiněných usní, resp. výrobků $\mathrm{z}$ nich. Toto sekundární barvení lícové strany bylo u opasků zachyceno pouze $\mathrm{v}$ jediném př́ípadě, a to na části prosekávaného opasku z Uherského Hradiště. $\mathrm{K}$ dosažení odlišného barevného vzhledu byl použit cinabarit (rumělka; více Hoch a kol. 2017, 166). Analogický způsob barvení je doložen na pochvě ze souboru z Prahy (lokalita Jámy; Figura, v tisku) nebo na opasku z Yorku (Mould-Carlisle-Cameron 2003, 3392-3393). ${ }^{7}$

Ražení, rytí a lisování (kat. č. 16, tab. IV) raznicemi (příp. rydlem) do materiálu přichází do módy ve velkém měřítku až v průběhu 15. století. Ražení je technika založená na práci s vlhkou usní, do které se tvarovaným nástrojem (raznicí) s pomocí kladiva otiskují zdobné motivy nebo jen otisky nástroje. Tímto způsobem lze tvořit celé obrazce. Lisování usně bylo nejsložitější a nejefektivnější technikou ve středověku, přičemž lisované motivy dostávaly plastický tvar díky užití formy (Figura, v tisku). Z našeho území pochází prozatím jediný nález takto zdobeného opasku z přelomu 15. a 16. z Tábora (Krajíc 1998, 123-125, 153).

Obšiváni okrajů (kat. č. 17-18; tab. V) je další ze způsobů výzdoby usňových opasků. Jednoduchá technika obšití hrany nití (velice pravděpodobně barevně odlišnou) měla opět jak ozdobný, tak funkční (zpevňovací) efekt. Doložena je prozatím na dvou nálezech (Uherské Hradiště, Jihlava).

\subsection{Nezdobené opasky, řemeny, řemínky}

Samostatnou skupinou jsou nijak nezdobené pruhy usní, které mohou mít v těle jeden a více otvorů indikujících jejich použití právě jako jednoduché opasky, řemeny či popruhy (tab. V:3). Nachází se ve fragmentech v hojném počtu téměř v každém souboru, často je z jejich stavu patrné, že byly intenzivně namáhány. Jejich původní funkci již není možné určit. Poslední množinu nálezů představují relativně rovně vykrojené, mnohdy deformované, nezdobené či jinak neupravované fragmenty a úseky pásů, řemenů a řemínků, jejichž původní funkce mohly být opět různé. U extrémně tenkých řemínků (do ca $5 \mathrm{~mm}$ ) se dá uvažovat, že mohly sloužit jako řemínky obuvi.

\section{Závěr}

K usňovým opaskům z našeho území je možné za současného stavu poznání říci, že jejich nízké počty, fragmentárnost, rozměry a způsoby výzdoby korespondují až na výjimky s nálezy ze zahraničí. Naopak odlišné se prozatím zdají být doložené způsoby výroby, kdy postrádáme zejména techniku přehýbání (a následného sešivání). V nálezech dominuje hovězina, případně teletina, výjimečně se vyskytne i kozina. Žádný z opasků se nedochoval kompletní, nejdelší měřil ca $700 \mathrm{~mm}$. Měřitelné byly naopak šířky, které oscilují mezi ca 10 až $47 \mathrm{~mm}$, ovšem rozměry mohou být zkreslené (zmenšené) vlivem konzervace provedené v minulosti. Síla použitého materiálu se pohybovala kolem 1 až $3 \mathrm{~mm}$, údaj může být ovšem opět mírně zkreslený. Ve způsobu

7 Červeně zbarvené opasky, koňské postroje, závěsy pochev pobočných zbraní apod. se pravidelně vyskytují v ikonografických pramenech. 
výzdoby, který se prozatím stal také základním kritériem pro dělení, se nejčastěji uplatňovalo prosekávání drobných, blízko sebe kladených otvorů tvořících jednoduché geometrické či stylizované tvary. Je pravděpodobné, že otvory byly ještě dále prošívány nití. Tento způsob výzdoby zdá se dominuje ve 13. století a vyznívá v průběhu století následujícího (spíše až v jeho druhé polovině). Dále je doloženo obšívání okrajů, použití metalických aplikací, polychromie a ražba kombinovaná s lisováním.

Problematice opasků jako celku nebyla, až na čestné výjimky (srov. Mazáčová 2012), v naší odborné literatuře věnována náležitá pozornost, a to i přes fakt, že tzv. pásy byly důležitou součástí stř̌edověkého oděvu, kombinující užitnou a symbolickou funkci. Mezi faktory, které mohou být př́ičinou této skutečnosti, patří řídký výskyt odpovídajících artefaktů v archeologických nálezech a celkové dřívější „opomíjeni““ usní jako archeologického materiálu (srov. Hoch 2020, 4-5). Předkládaný text si neklade za cíl tuto problematiku jednou provždy vyřešit, ale pouze představit doposud nashromážděné nálezy a nastínit možnosti další práce s tímto nesmírně zajímavým dokladem středověké hmotné kultury.

\section{Katalog $^{8}$}

\section{Prosekávaný opasek (dvoudílný) (tab. I:1)}

Místo nálezu: Cvilínek u Černova, odpadní vrstvy (montánní areál); rozměry: d. 220, š. $47 \mathrm{~mm}$, s. $2 \mathrm{~mm}$; materiál: hovězina; datace: 2. polovina 13. století; uloženi: Muzeum Vysočiny Jihlava; literatura: Hrubý a kol. 2012; Hoch 2020, katalog.

Nejširší opasek v souboru. Připočteme-li i možné smrštění způsobené konzervací, mohla jeho šíře dosahovat $50 \mathrm{~mm}$. Materiál použitý na výrobu byl opotřebovaný (ošoupaný, otřený) a netypicky zdvojený. Obě téměř identické poloviny k sobě musely být původně sešity právě skrz ozdobné prosekávané otvory. Opasek byl díky tomu zřejmě extrémně pevný a pravděpodobně se při jeho výrobě počítalo $s$ faktem, že bude snášet větší zátěž. $V$ tomto kontextu je jistě zajímavé, že obdobné opasky o šířce kolem 50 až $60 \mathrm{~mm}$ jsou autory publikace o nálezech z Londýna interpretovány jako možné opasky k pochvám mečů (Mould-Carlisle-Cameron 2003, 3392). V rámci specifického hornického prostředí však mohl mít takovýto extra pevný opasek či řemen zcela jiné využití. Opasek sešívaný ze dvou kusů usně byl nalezen např́iklad také v polském Štětíně (Kowalska 2013, 174). Na rozdíl od nálezu z Černova však autorka uvádí, že horní i spodní vrstva měly každá jiné děrování.

\section{Prosekávaný opasek (tab. I:2)}

Místo nálezu: Cvilínek u Černova, odpadní vrstvy (montánní areál); rozměry: d. $218 \mathrm{~mm}$, š. 25 mm; materiál: hovězina; datace: 2. polovina 13. století; uložení: Muzeum Vysočiny Jihlava; literatura: Hrubý a kol. 2012; Hoch 2020, katalog.

Část opasku zdobená linií prosekávaných otvorů podél okrajů a pravidelně se opakujícími paprsčitě ukládanými záseky do tvaru kruhu, kladenými uprostřed.

\section{Prosekávaný opasek (s kostěnou přezkou) (tab. II:1a, b)}

Misto nálezu: Uherské Hradiště, Mariánské nám., odpadní sídlištní vrstvy (parcela); rozměry: opasek d. $420 \mathrm{~mm}$, š. 15-20 mm, přezka průměr $33 \mathrm{~mm}$; materiál: teletina/hovězina; datace: 60. léta 13. století; uloženi: Slovácké muzeum v Uherském Hradišti; literatura: Hoch 2020, katalog.

8 Katalog vychází z autorovy disertační práce (Hoch 2020), byl ovšem pro účely tohoto příspěvku zrevidován a upraven. 

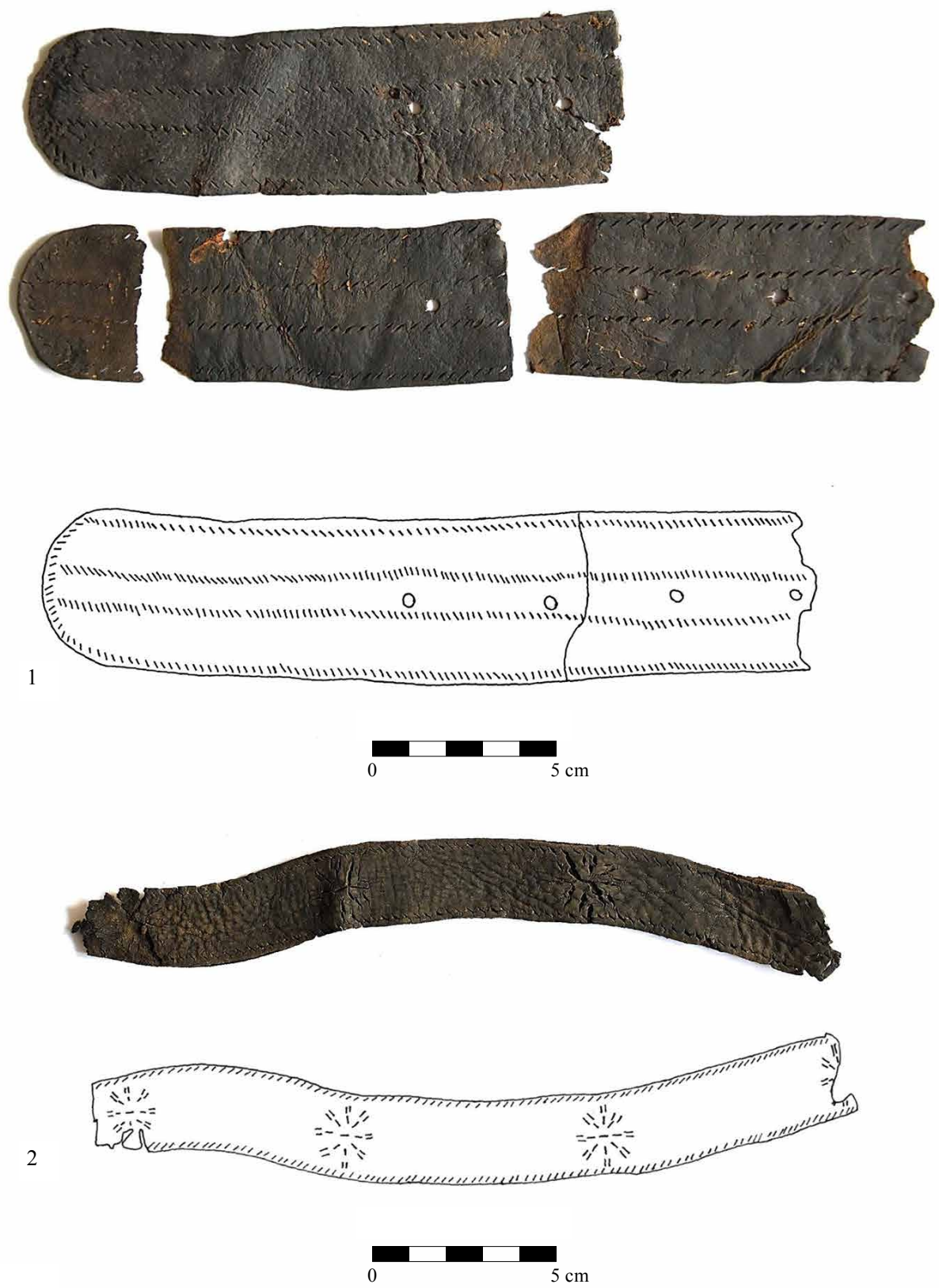

Tab. I

Tab. I. 1-2 - prosekávané opasky, Cvilínek u Černova. Foto a kresba A. Hoch.

Taf. I. 1-2 - gestanzte Gürtel, Cvilínek u Černova. Foto und Zeichnung A. Hoch. 
Výjimečně dochovaná část opasku s kruhovou přezkou a trnem, zdobená prosekáváním v podobě jedné linie otvorů při okrajích a jedné linie jdoucí stř̌edem. Středová linie je ovšem kratší než okrajové a doplňuje ji v pravidelných rozestupech motiv stylizovaného kolečka. Rám přezky byl vysoustružen z kosti, k výrobě trnu posloužilo železo. Materiál použitý na přezku napovídá, že opasky v tomto provedení zřejmě nelze považovat za luxusní zboží, ale za běžně vyráběný a dostupný oděvní doplněk. B. Kowalska uvádí na př́ikladech nálezů ze Štětína, že takto zdobené opasky byly hojné a oblíbené zejména u obyvatel předměstí (Kowalska 2013, 178). Identická kruhová kostěná přezka se zbytky usně byla nalezena také na předhradí nedalekého hradu ve Veselí nad Moravou a datována je taktéž do druhé poloviny 13. století (k. č. 12). Také zvolený způsob výzdoby má přímou analogii v dalším fragmentu z veselského předhradí (k. č. 4). Nabízí se tak otázka možnosti distribuce výrobků uherskohradišt'ských řemeslníků na veselský hrad, vzdálený od centra města prribližně $15 \mathrm{~km}$ vzdušnou čarou. Analogický nález k oběma přezkám pochází ze zaniklého městečka Hradišt'ko u Davle, kde se podařilo objevit celý soubor těchto kostěných kruhových přezek, datovaných do druhé poloviny 13. století. S velkou pravděpodobností se na lokalitě také přímo vyráběly (Richter 1982, 190-191). Ze zahraničí je známe krom výše zmíněného Štětína také například z polského Kolobřehu, kde byl nalezen kompletní opasek dochovaný v celé délce $(160 \mathrm{~cm})$ i se všemi kováními.

\section{Prosekávaný (prošivaný) opasek (tab. II:2)}

Misto nálezu: Veselí nad Moravou, předhradí, odpadní sídlištní vrstvy; rozměry: d. $142 \mathrm{~mm}$, š. 20 mm; materiál: neurčitelný; datace: 2. polovina 13. století; uložení: Archaia Brno; literatura: Hoch 2015; 2020, katalog.

Fragment prosekávaného opasku zdobený při obou okrajích jednoduchou linií. Ta se táhne i pomyslným středem a končí přibližně před polovinou předmětu. Tato středová linie je navíc zdobena motivem stylizovaného kolečka. U tohoto opasku jsou kolem ozdobných otvorů u okrajových linií patrné otlaky šicí nitě, byl tedy prokazatelně také prošívaný.

\section{Prosekávaný opasek (tab. III:1)}

Misto nálezu: Hradec Králové, Velké nám. čp. 143-144, sídlištní vrstvy (parcela); rozměry: d. 190 mm, š. 23 mm; materiál: neurčitelný; datace: 2. polovina 13. až 14. století; uložení: Muzeum východních Čech v Hradci Králové; literatura: Hoch 2020, katalog.

Část prosekávaného opasku zdobená motivem linií a klikatek. Oproti jiným nálezům tohoto typu jsou otvory netypicky drobné a spíše kruhové.

\section{Prosekávaný opasek (tab. III:2)}

Misto nálezu: Hradec Králové, Velké nám. čp. 143-144, sídlištní vrstvy (parcela); rozměry: d. $255 \mathrm{~mm}$, š. $23 \mathrm{~mm}$; materiál: hovězina (?); datace: 2. polovina 13. až 14. století; uložení: Muzeum východních Čech v Hradci Králové; literatura: Hoch 2020, katalog.

Část opasku zdobená prosekávanými otvory tvořícími linii při okrajích a částečně i středu, místy doplněná krátkými čarami z otvorů kladených svisle.

\section{Prosekávaný opasek (tab. III:3)}

Misto nálezu: Hradec Králové, Velké nám. čp. 143-144, sídlištní vrstvy (parcela); rozměry: d. 60, š. $25 \mathrm{~mm}$; materiál: hovězina (?); datace: 2. polovina 13. až 14. století; uložení: Muzeum východních Čech v Hradci Králové; literatura: Hoch 2020, katalog.

Malý fragment opasku zdobený při obou okrajích dvěma liniemi z drobných, spíše kulatých vpichů. 


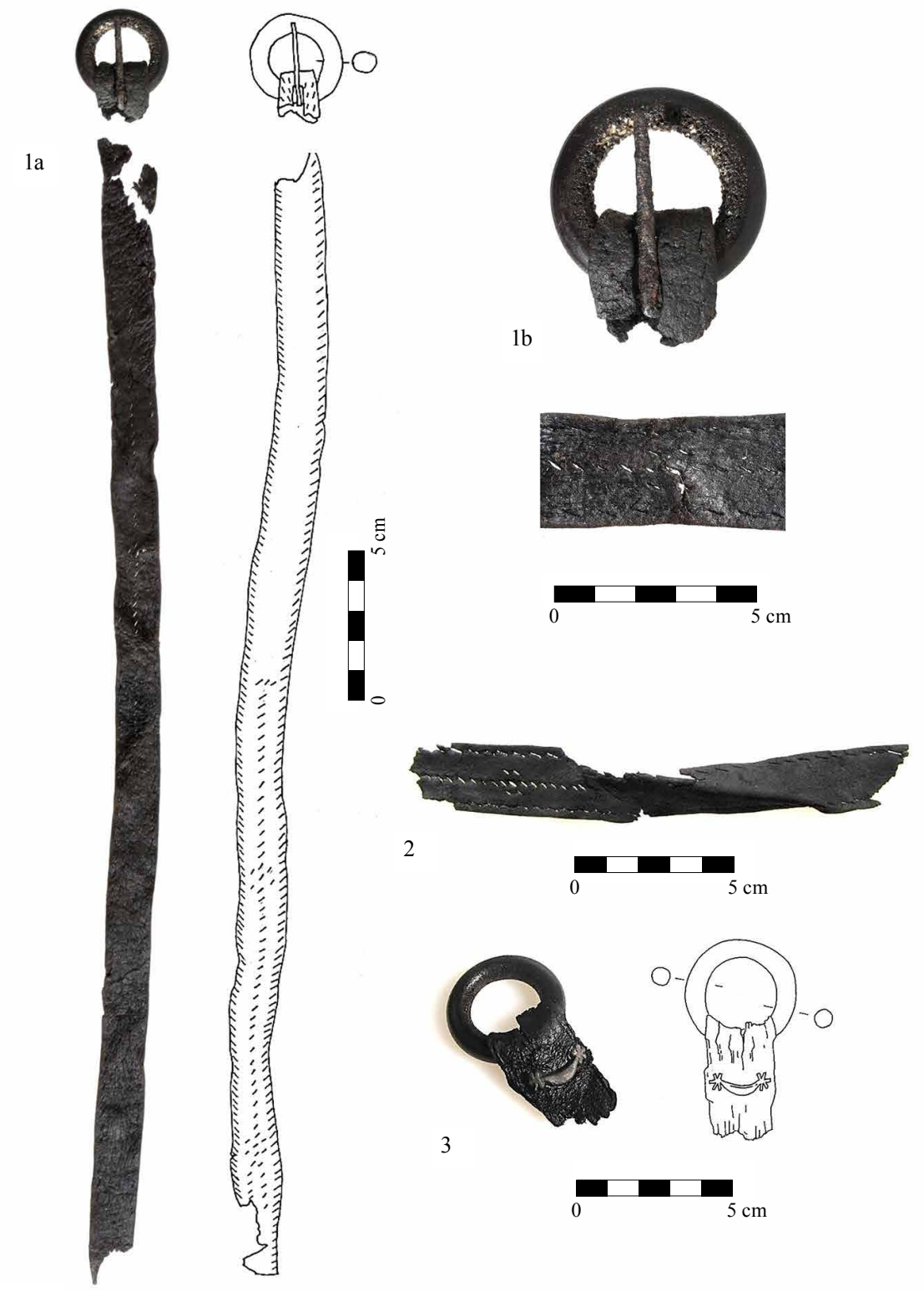

Tab. II

Tab. II. 1a - prosekávaný opasek s kruhovou kostěnou přezkou; 1b - detail přezky a prosekávaného výzdobného motivu, Uherské Hradiště (foto Slovácké muzeum v Uherském Hradišti, kresba A. Hoch); 2 - část prosekávaného opasku, Veselí nad Moravou (foto A. Hoch); 3 - fragment opasku s kruhovou kostěnou přezkou zdobený metalickou aplikací (kresba Š. Trávníčková, foto A. Hoch).

Taf. II. 1a - gestanzter Gürtel mit runder Schnalle aus Bein; 1b - Detail der Schnalle und des gestanzten Ziermotivs, Uherské Hradiště (Foto Museum der Mährischen Slowakei in Uherské Hradiště, Zeichnung A. Hoch); 2 - Teil eines gestanzten Gürtels, Veselí nad Moravou (Foto A. Hoch); 3 - Gürtelfragment mit runder Schnalle aus Bein und Metallapplikationen (Zeichnung Š. Trávníčková, Foto A. Hoch). 


\section{Prosekávaný opasek (tab. III:4)}

Misto nálezu: Hradec Králové, Velké nám. čp. 143-144, sídlištní vrstvy (parcela); rozměry: d. $136 \mathrm{~mm}$, š. $20 \mathrm{~mm}$; materiál: hovězina (?); datace: 2. polovina 13. až 14. století; uložení: Muzeum východních Čech v Hradci Králové; literatura: Hoch 2020, katalog.

Do oblouku vykrojená část opasku (?) zdobená dvojitou středovou linií otvorů a velice jednoduše provedeným oválem. Může teoreticky pocházet i z jiného předmětu.

\section{Prosekávaný opasek (tab. III:5)}

Misto nálezu: Hradec Králové, Velké nám. čp. 143-144, sídlištní vrstvy (parcela); rozměry: d. $170 \mathrm{~mm}$, š. $15 \mathrm{~mm}$; materiál: neurčitelný; datace: 2. polovina 13. až 14. století; uložení: Muzeum východních Čech v Hradci Králové; literatura: Hoch 2020.

Koncová část opasku bez viditelných stop po přichycení nákončí. Zdobení pomocí tří řad šikmo ukládaných otvorů je protaženo až na koncový hrot.

\section{Prosekávaný opasek (tab. III:6)}

Místo nálezu: Litovel, nám. Přemysla Otakara II., sídlištní vrstvy; rozměry: d. 70 mm, š. 20 mm; materiál: neurčitelný; datace: 2. polovina 13. století; uloženi: Národní památkový ústav, ÚOP Olomouc; literatura: Hoch 2020, katalog.

Fragment opasku ze silnější usně (přes $2 \mathrm{~mm}$ ) zdobený třemi liniemi prosekávaných otvorů.

\section{Prosekávaný opasek (tab. III:7)}

Místo nálezu: České Budějovice, nám. Přemysla Otakara II., sídlištní vrstvy; rozměry: d. 140 mm, š. 40 mm; materiál: neurčitelný; datace: 2. polovina 13. století; uložení: Jihočeské muzeum v Českých Budějovicích; literatura: Hoch 2018; 2020.

Fragment poměrně širokého opasku zdobeného $\mathrm{v}$ těle čtyřmi rovnými řadami šikmých otvorů, mezi nimiž se vine obdobně provedený motiv vlnovky.

\section{Opasek s metalickou aplikací a kostěnou přezkou (tab. II:3)}

Misto nálezu: Veselí nad Moravou, předhradí, odpadní sídlištní vrstvy; rozměry: opasek d. $14 \mathrm{~mm}$, š. $27 \mathrm{~mm}$; přezka průměr $41 \mathrm{~mm}$; materiál: neurčitelný; datace: 2. polovina 13. století; uložení: Archaia Brno; literatura: Hoch 2015; 2020, katalog.

Krátká část opasku se soustruženou kruhovou přezkou. Useň za přezkou spojena pomocí nýtované metalické aplikace. Aplikace má podobu dvou květů či pěticípých hvězd obloukovitě propojených v místě šestého cípu. Materiál, ze kterého byla aplikace vyrobena, dosud nebyl analyzován. Vzhledem k jeho stř́břité barvě se dá předpokládat slitina olova a cínu.

\section{Opasek s metalickými aplikacemi (tab. IV:1)}

Místo nálezu: Hradec Králové, Šatlava, odpadní jímka; rozměry: d. 705 mm, š. 200 mm; materiál: kozina; datace: 14. století; uložení: Muzeum východních Čech v Hradci Králové; literatura: Hoch 2020, katalog.

Dlouhý úsek opasku původně zdobený metalickými aplikacemi. Na výrobu byla použita relativně silná (až $3 \mathrm{~mm}$ ) kozina. Do této skupiny opasků jej řadí minimálně 22 identifikovaných negativů po úzkých obdélných kovových aplikacích. Negativy mají podobu dvou drobných otvorů procházejících skrz materiál a umístěných v ne zcela pravidelných rozestupech při horním i spodním okraji. Mezi otvory pak zůstal po aplikaci otisk v líci, který však není natolik výrazný, 

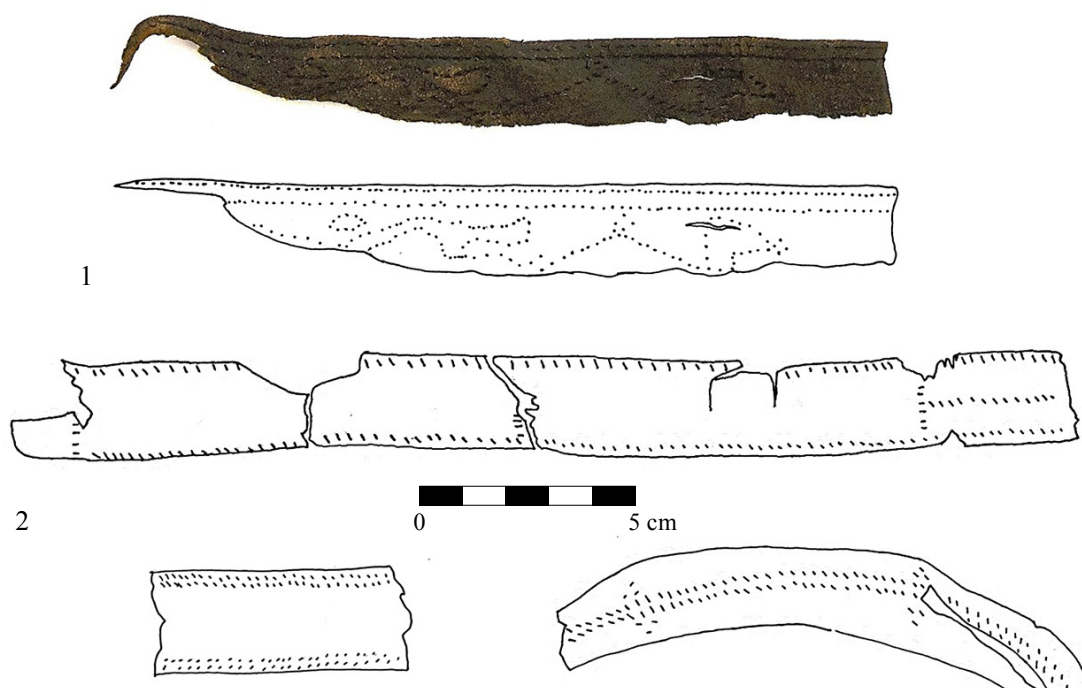

3
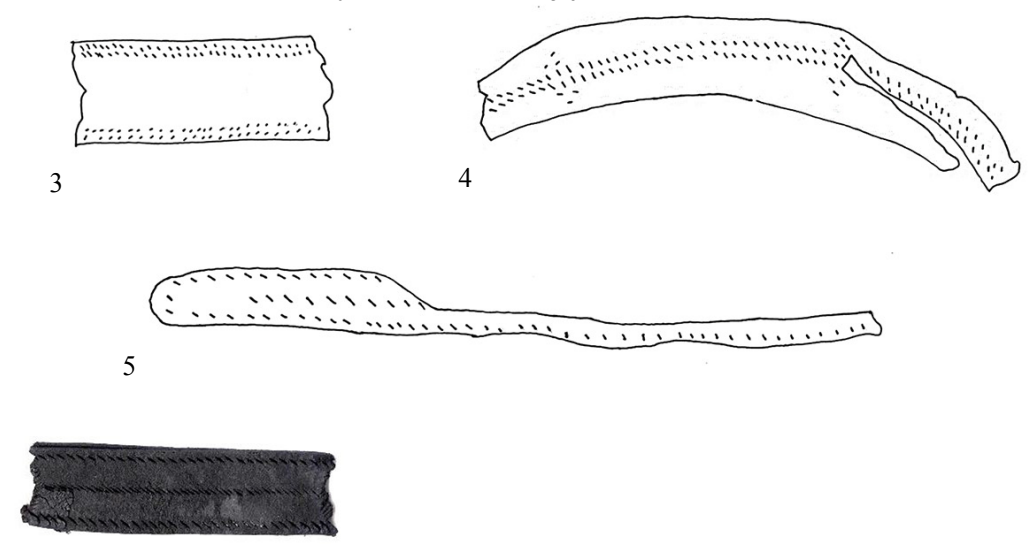

6
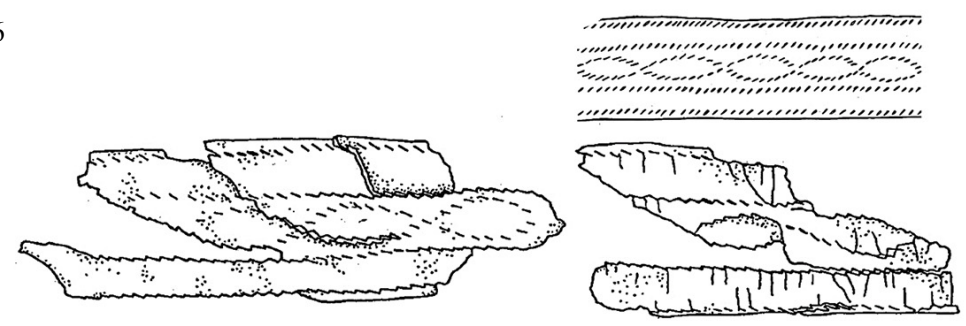

7

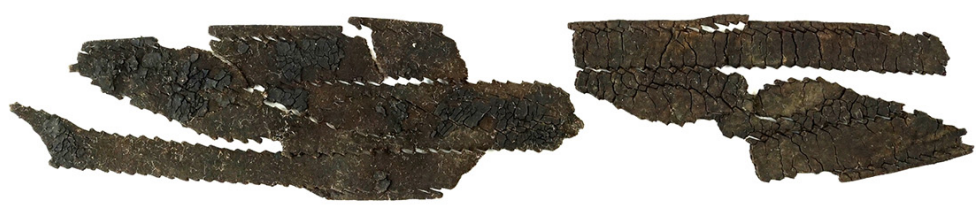

Tab. III

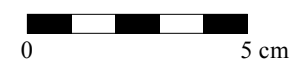

Tab. III. Prosekávané opasky. 1-5 - Hradec Králové (foto a kresba A. Hoch); 6 - Litovel (foto A. Hoch); 7 - České Budějovice (kresba Jihočeské muzeum v Českých Budějovicích; foto A. Hoch).

Taf. III. Gestanzte Gürtel. 1-5 - Hradec Králové (Foto und Zeichnung A. Hoch); 6 - Litovel (Foto A. Hoch); 7 - České Budĕjovice (Zeichnung Südböhmisches Museum in České Budějovice; Foto A. Hoch). 
aby bylo možné určit přesný typ. Opasek má v materiálu ještě několik dílčích drobných kulatých otvorů a také úzkých a krátkých vodorovných trhlin, které mohou být pozůstatkem po usňových řemíncích či závěsech. Výběr materiálu a počet kování jej jednoznačně řadí do kategorie lepšího zboží. Nález usňového opasku s kovovými aplikacemi pochází z našeho území například z Č́slavi (Frolík a kol. 1999, 296) či Prahy (Figura 2019, 130).

\section{Opasek s metalickou aplikaci (tab. IV:2)}

Misto nálezu: Jihlava, ul. Dominikánská, odpadní jímka; rozměry: d. 158 mm, š. 9 mm; materiál: teletina/hovězina; datace: 2. polovina 14. až 1. polovina 15. století; uložení: Muzeum Vysočiny Jihlava; literatura: Hoch 2015a.

Fragment úzkého opasku vyrobený z hověziny či teletiny má uprostřed dochované části drobnou kruhovou vypouklou aplikaci - tzv. pukličku. Ozdoba je z polymetalického kovu a samostatně se vyskytuje poměrně často (srov. Šlancarová 2016, 156-157). Po dalších pukličkách se v materiálu dochovaly otvory v rozestupu přibližně $35 \mathrm{~mm}$. S velkou pravděpodobností se jedná o část úzkého opasku (či řemene), jaký bývá $\mathrm{k}$ vidění i v ikonografických pramenech. Často byl nošen spolu s dýkou křížem přes rameno a hrud'. Taková iluminace se váže i přímo k Jihlavě, na vyobrazení má úzký, kruhovými aplikacemi zdobený opasek s dýkou, křížem zavěšen jeden z členů městské rady (obr. 4). Zajímavý je i fakt, že iluminace pochází ze slavného jihlavského Gelnhausenova kodexu, jehož vznik je kladen na přelom 14. a 15. století, tedy obdobně jako tento fragment.

\section{Polychromovaný prosekávaný opasek (tab. IV:3)}

Misto nálezu: Uherské Hradiště, Zelný trh, sídlištní vrstvy (dvůr parcely); rozměry: d. 103 mm, š. $20 \mathrm{~mm}$; materiál: kozina; datace: 2. polovina 13. až 14. století; uložení: Slovácké muzeum v Uherském Hradišti; literatura: Hoch a kol. 2017; Hoch 2020, katalog.

Č́st opasku vyrobeného ze silnějšího materiálu (přes $2 \mathrm{~mm}$ ), identifikovaného jako kozina. Zdobení je provedeno formou drobných zdvojených otvorů přibližně oválného tvaru proseknutých skrz materiál $\mathrm{v}$ řadě podél obou delších okrajů. Na jednom $\mathrm{z}$ konců pak tento dvojřad kolmo protíná několik dalších, tvarově odlišných (užších) otvorů. Ačkoliv je technika provedení výzdoby běžná, liší se od předchozích skutečností, že otvory na tomto opasku jsou více oválné a v párech. Výjimečnými je činí fakt, že byly vyplněny červeným barvivem, jež se ve stopovém množství dochovalo téměř v každém z nich. Barvivo bylo identifikováno jako cinabarit neboli rumělka. Samotná barva není integrální součástí kủže, ale byla na povrch nanesena sekundárně. V současnosti již bohužel nelze určit celkový rozsah pokrytí, resp. zda byly takto zvýrazněny pouze otvory, či byl natřen celý povrch, což se jeví více pravděpodobné.

\section{Opasek zdobený ražením a lisováním (tab. IV:4)}

Místo nálezu: Tábor, Pražská čp. 220, studna / odpadní jímka; rozměry: d. 103 mm, š. 20 mm; materiál: neurčeno; datace: konec 15. až počátek 16. století; uložení: Husitské muzeum v Táboře; literatura: Krajíc 1998.

Z Tábora pochází dosud jediný doklad výzdoby ražením. Nachází se na opasku objeveném v domě na Pražské ulici čp. 220, známém jako Dům pasíře Prokopa (více Krajíc 1998). Táborský opasek, nalezený spolu s dalšími částmi řemenů a polotovarů, dokládá v domě pasířskou výrobu. Zdoben je pravidelně skládaným motivem raženým pomocí drobné raznice připomínající stylizovaný list či větvičku, doplněný lisovaným či rytým motivem dvouocasého lva. Na jednom z konců byl opatřen mosazným kováním s háčkem. Technikou ražení jsou zde zdobeny i další odřezy, které lze považovat za výrobní odpad (Krajíc 1998, 123-125, 153, obr. 64, 66, 195, 248, obr. 99). 

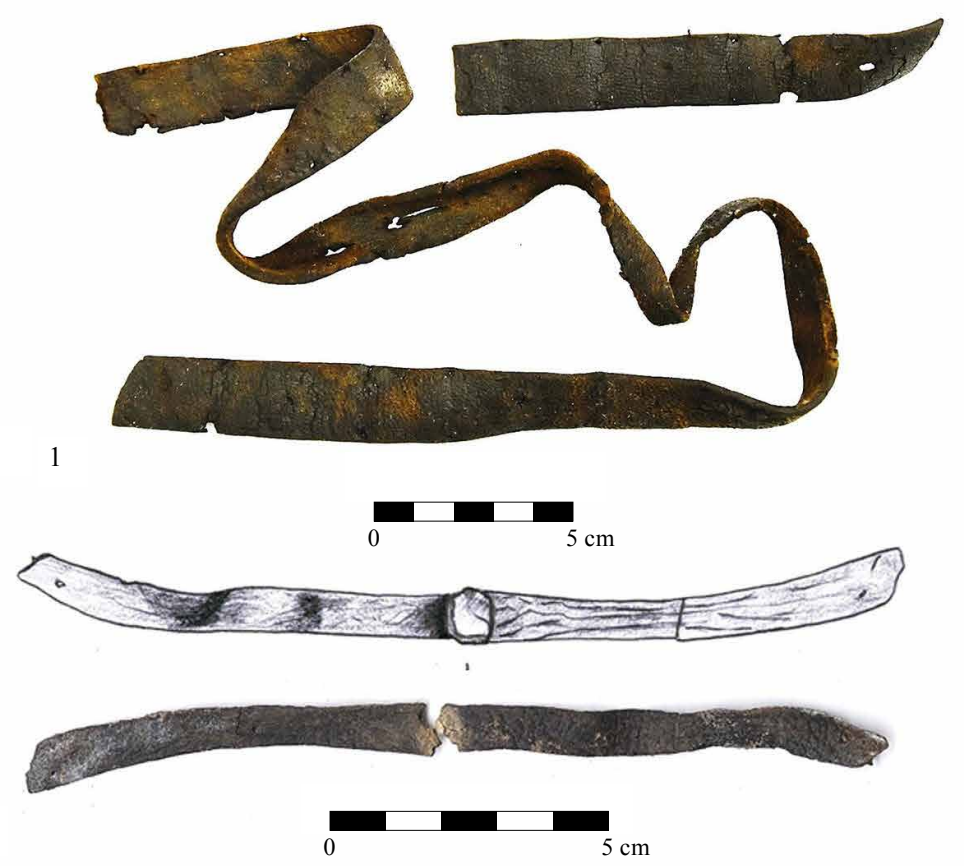

2
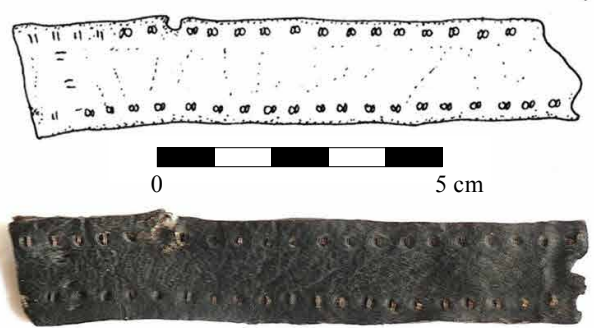

3
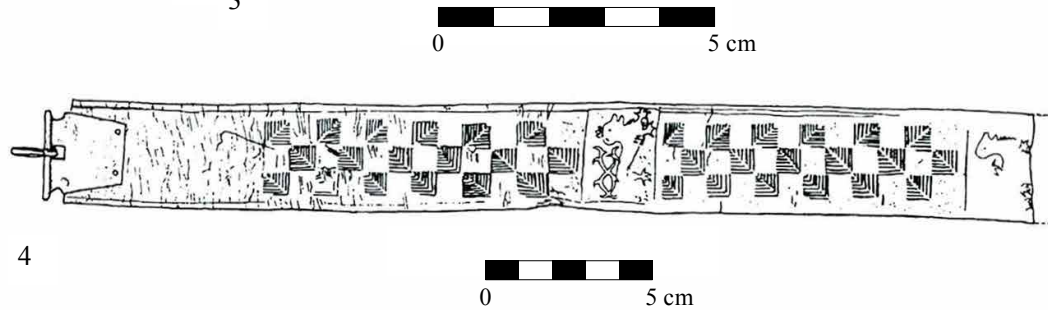

Tab. IV

Tab. IV. 1 - opasek zdobený metalickými aplikacemi, Hradec Králové (foto A. Hoch); 2 - opasek zdobený metalickými aplikacemi, Jihlava (kresba E. Bílková Šamalová, foto A. Hoch); 3 - opasek zdobený polychromií a prosekáváním, Uherské Hradiště (kresba L. Běhounková, foto A. Hoch); 4 - opasek zdobený rytím a lisováním (podle Krajíc 1998).

Taf. IV. 1 - Mit Metallapplikationen verzierter Gürtel, Hradec Králové (Foto A. Hoch); 2 - mit Metallapplikationen verzierter Gürtel, Jihlava (Zeichnung E. Bílková Šamalová, Foto A. Hoch); 3 - mit Polychromie und Stanzung verzierter Gürtel, Uherské Hradiště (Zeichnung L. Běhounková, Foto A. Hoch); 4 - Gürtel mit Ritz- und Stanzverzierung (nach Krajíc 1998). 
17. Obšívaný opasek (tab. V:1)

Místo nálezu: Jihlava, ul. Dominikánská, odpadní jímka; rozměry: d. 700 mm, š. 30-38 mm; materiál: neurčitelný; datace: 2. polovina 14. až 1. polovina 15. století; uložení: Muzeum Vysočiny Jihlava; literatura: Hoch 2015a.

Na tři fragmenty roztržená část opasku. Jeden úsek s obšitou hranou, zbylé části prošité střídavě i podél okraje. V těle materiálu jsou místy chaoticky ukládané otvory vzniklé po dalším šití (přidané řemínky?). Opasek působí spíše jako produkt domácké výroby.

\section{Obšívaný opasek (tab.: V:2)}

Misto nálezu: Uherské Hradiště, Prostřední ul., sídlištní vrstvy (parcela); rozměry: d. $354 \mathrm{~mm}$, š. 27-34 mm; materiál: hovězina (?); datace: 2. polovina 13. až 14. století; uložení: Slovácké muzeum v Uherském Hradišti; literatura: Hoch-Bartík 2020.

Koncová část opasku s dobře patrným otiskem (otlakem) po našití obdélného nákončí (nedochovalo se). Oba okraje měly původně obšitou hranu, šicí nit’ se ovšem nedochovala. Nelze vyloučit, že opasek byl původně zdvojený.

\section{Literatura}

ANTONÍN MALANÍKOVÁ, M., 2012: Materiální kultura brněnských domácností 15. století v zrcadle testamentů, BMD 25, 61-77.

BRODSKÝ, P., 2012: Krása českých iluminovaných rukopisů. Praha.

BŘEZINOVÁ, H.-KOHOUT, D., 2016: Středověké textilní a barviř̌ské technologie. Soubor textilních fragmentů z odpadních vrstev z Nového Města pražského. Praha.

EGAN, G.-PRITCHARD, F., 2002: Dress accessories c. 1150-c. 1450. London.

FIGURA, J., 2019: Předběžná zpráva o nálezu souboru středověkých usní z tzv. Jámy na Novém městě v Praze, Staletá Praha XXXV, č. 2, 125-131.

- v tisku: Středověké technologie zpracování usní, Archeologia technica 39 (2020).

FINGERLIN, I., 1971: Gürtel des hohen und späten Mittelalters. Berlin.

FLORI, J., 2008: Rytíríi a rytířství ve středověku. Praha.

FROLÍK, J. a kol., 1999: Frolík, J.-Hazlbauer, Z.-Charvát, P.-Šumberová, R.-Tomášek, M., Čáslav: místo pro život: svědectví archeologie. Praha.

HOCH, A., 2015: Kožené artefakty. In: Plaček, M.-Dejmal, M. a kol., Veselí nad Moravou. Středověký hrad v říční nivě, 280-298. Brno.

- 2015a: Středověká kožedělná produkce z Jihlavy v odrazu hmotné kultury, AVV 6, 101-134.

- 2018: Středověká kožedělná produkce z Českých Budějovic v odrazu hmotné kultury, AVJČ 31, 253-277.

- 2020: Kožedělná výroba v českých zemích ve středověku. Rkp. disertační práce ulož. v ÚAM FF MU, Brno.

HOCH, A.-BARTÍK, J., 2020: Středověké usňové artefakty z vybraných lokalit v Uherském Hradišti (Stará radnice, Reduta, ul. Františkánská), Slovácko: společenskovědní sborník pro moravsko-slovenské pomezí LXI (2019), 87-104.

HOCH, A. a kol., 2017: Hoch, A.-Bartík, J.-Běhounková, L.-Malý, K., Středověké kožené artefakty ze Zelného trhu v Uherském Hradišti, Slovácko: společenskovědní sborník pro moravsko-slovenské pomezí LVII (2016), 157-173.

HRUBÝ, P. a kol., 2012: Hrubý, P.-Hejhal, P.-Hoch, A.-Kočár, P.-Malý, K.-Macháňová, L.-Petr, L.Štecl, J., Středověký úpravnický areál Cvilínek u Černova na Pelhřimovsku, PA CIII, 339-418.

IWAŃCZAK, W., 2001: Po stopách rytî́rských př́iběhů. Praha.

KOWALSKA, A. B., 2010: Wytwórczość skórzana w późnosredniowiecznej we wczesnośredniowiecznym Szczecinie. Szczecin.

- 2013: Wytwórczość skórzana w późnosredniowiecznej Dzielnicy Chyzyńskiej w Szczecinie. Szczecin. 

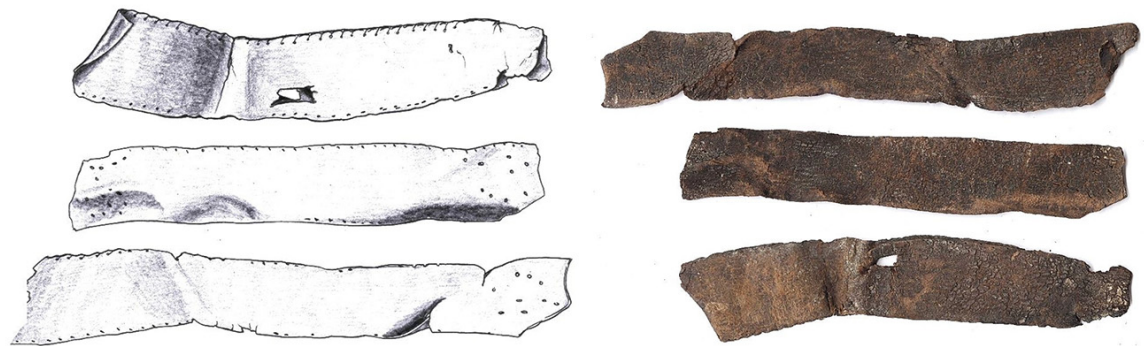

1
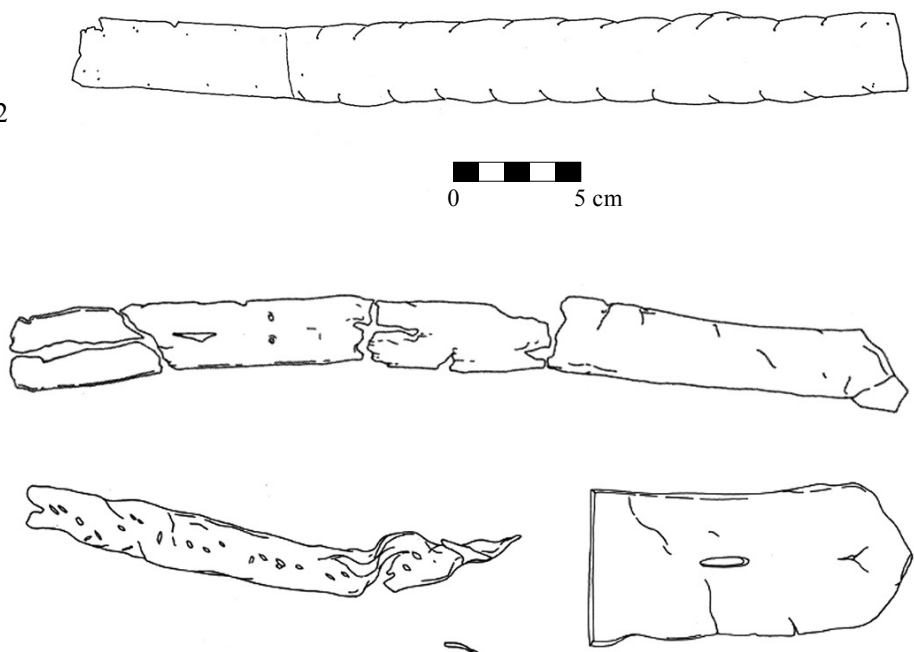

3

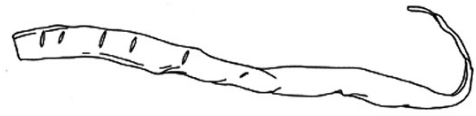

0

$5 \mathrm{~cm}$

Tab. V

Tab. V. 1 - opasek zdobený obšíváním, Jihlava (kresba E. Bílková Šamalová, foto A. Hoch); 2 - opasek zdobený obšíváním, Uherské Hradiště (foto a kresba A. Hoch); 3 - řemeny, řemínky, popruhy, Veselí nad Moravou (kresba Š. Trávníčková).

Taf. V. 1 - Gürtel mit Steppverzierung, Jihlava (Zeichnung E. Bílková Šamalová, Foto A. Hoch); 2 - Gürtel mit Steppverzierung, Uherské Hradiště (Foto und Zeichnung A. Hoch); 3 - Riemen, Riemchen, Schlaufgurte, Veselí nad Moravou (Zeichnung Š. Trávníčková). 
KRAJÍC, R., 1998: Dům pasíře Prokopa. Archeologický výzkum odpadní jímky v domě čp. 220. Tábor.

KRÁSA, J., 1990: České iluminované rukopisy 13./16. století. Praha.

KYBALOVÁ, M., 2001: Dějiny odívání. Stř̌edověk. Praha.

LAWRYNOWICZ, O., 2005: Średniowieczny pas rycerski na Śląsku i w Małopolsce. Studium ikonograficzne, Kwartalnik Historii Kultury Materialnej 53, č. 1, 3-15.

MACHÁŇOVÁ, L., 2007: Hmotná kultura na příkladu drobných kovových, kostěných a keramických předmětů 13.-15. století v jihlavském mikroregionu. Rkp. magisterské diplomové práce ulož. v ÚAM FF MU, Brno.

MAZÁČOVÁ, P., 2012: Opasek jako symbol a součást stř̌edověkého oděvu. Př́íspěvek k hmotné kultuře českého středověku. Praha.

MIAZGA, B., 2018: Wyniki badań spektrálních średniowiecznych zdobionych zabytków. In: Rytm rozwoju miasta na kulturowym pograniczu. Studium strefy placu Nowy Targ we Wrocławiu. Wratislavia Antiqua 23 (Piekalski, J.-Wachowski, K., edd.), 794-849. Wrocław.

MOULD, Q.-CARLISLE, I.-CAMERON, E., 2003: Craft, Industry and Everyday Life: Leather and Leatherworking in Anglo-Scandinavian and Medieval York. York.

PILNÁ, V., 2018: Oděv v západních Čechách 15. až 17. století. Plzeň.

PROCHÁZKA, R., 1990: Kovové předměty z výbavy středověkého měštana z výzkumů v Brně - Pekařské ulici - Metallgegenstände der Ausstattung der mittelalterlichen Bürgers aus der Ausgrabung in Brno Pekařská ulice (Vorläufiger Bericht), AH 15, 99-109.

RICHTER, M., 1982: Hradišt'ko u Davle - městečko ostrovského kláštera. Praha.

SHROMÁŽDILOVÁ, I., 2001: Kožedělná výroba v Uherském Hradišti ve středověku, Slovácko XLII (2000), 149-157.

SCHNACK, K., 1994: Mittelalterliche Lederfunde aus Konztanz. Stuttgart.

- 1998: Mittelalterliche Lederfunde aus Schleswig: Futterale, Riemen, Taschen und andere. Objekte: Ausgrabung Schild 1971-1975. Neüminster.

SCHOPPHOFF, C., 2009: Der Gürtel. Funktion und Symbolik eines Kleidungsstück in Antike und Mittelalter. Köln.

WALTHER, I. F.-SIEBERT, G., 1992: Codex Manesse, Die Miniaturen der Großen Heidelberger Liederhandschrift. Frankfurt am Main.

WYWROT-WYSZKOWSKA, B., 2008: Skórnictwo w lokacyjnym Kolobrzegu. XIII-XV wiek. Szczecin.

WYWROT-WYSZKOWSKA, B.-JANOWSKI, A., 2017: Mieszczański pas naddługi z późnośredniowiecznego Kołobrzegu, Kwartalnik Historii Kultury Materialnej 65, č. 2, 209-219.

ŠLANCAROVÁ, V., 2016: Podoba středověkého šperku na základě jihomoravských nálezů. Rkp. disertační práce uložený v ÚAM FF MU, Brno.

-2018: Středověkýšperk.Archeologickénálezyzjižní Moravy.Brno.https://doi.org/10.5817/CZ.MUNI.M210-9021-2018

ZELENKA, J., 2014: Turnaje a hry. In: Dvořáčková-Malá, D.-Zelenka, J. a kol., Přemyslovský dvůr. Život knížat, rytířů a králů ve stř̌edověku. Praha.

ZŮBEK, A., 2002: Středověké přezky v brněnských nálezech, SPFFBU M 7, 123-153.

\section{Internetové zdroje}

Dobra. Dostupné z: https://www.dobraczech.cz/, cit. 15. 5. 2021.

\section{Zusammenfassung}

\section{Mittelalterliche Ledergürtel in archäologischen Funden}

Nicht nur der Problematik von Ledergürteln wurde in der tschechischen Forschergemeinde bislang keine gebührende Aufmerksamkeit entgegengebracht. Die bisher einzige Arbeit zu 
diesem Thema ist eine Publikation von J. Mazáčová (2012). Das Interesse wurde zumeist nur mit ihren Metallkomponenten in Verbindung gebracht wie etwa Schnallen und Riemenzungen oder ggf. Zierapplikationen (Procházka 1990; Macháňová 2007; Zůbek 2002; Šlancarová 2016; 2018 u.a.). Mit Gürteln, besonders jedoch ihren Herstellern - den Gürtelmachern - beschäftigt sich auch eine Publikation von R. Krajíc (1998).

Der Gürtel (lat. cingulum) war ein wichtiges Accessoire der mittelalterlichen Kleidung. Wegen seines schmuckvollen Aussehens und höherem Materialwert wurden Gürtel häufig in Testamente aufgenommen (mehr dazu siehe etwa Antonín Malaníková 2012, 63-54). Man unterschied zwischen Leder-, Textil- und Metallgürteln, zwischen farbigen, engen, breiten, extrem langen, kurzen und solchen, die mit Schnallen, Haken und Schließen zusammengehalten wurden. Im Zusammenhang mit Gürteln fanden auch Gegenstände Erwähnung, die an ihnen üblicherweise getragen wurden, wie Waffen, Messer, Geldbörsen, Taschen, Beutel, Schlüssel, Behälter u.ä. (Zíbrt 1892, 343; Mazáčová 2012, 36). Eine unentbehrliche Rolle hatten Gürtel beim Akt des Ritterschlags (Abb. 2; vgl. Zelenka 2012; Iwańczak 2000; Flori 2003, Mazáčová 2012, 9-18 u.a.).

Funde nicht nur von Ledergürteln, besonders solcher in teurer Ausführung, sind in tschechischem archäologischen Umfeld nicht allzu häufig. Die hier vorgelegte Kollektion wurde aus mehr als siebentausend Artefakten von vierzig in die Zeitspanne vom 13. bis Anfang 16. Jahrhundert datierten Fundstätten ausgewählt (siehe Hoch 2020, 51-56). Diese Tatsache ist auf die historische und natürliche Ebene zurückzuführen. Zier- und Luxusgürtel wurden als wertvoller Besitz angesehen (Schmuck), der häufig vererbt wurde. Die zweite Ursache ihres geringen Vorkommens in archäologischen Funden sind natürliche Prozesse. Gürtel wurden sowohl aus vegetabil gegerbtem Leder, das gegen Fäulnis- und Zersetzungsprozesse widerstandsfähig ist, als auch aus den übrigen Typen hergestellt, die bereits einer Zersetzung unterliegen. Damit gelangt man zur Grundtypologie von Gürteln, die je nach Material unterteilt werden können in Leder-, Textil- und Metallgürtel (ggf. kombiniert). Die einzelnen Typen pflegt man beispielsweise auch nach ihrer Form und Konstruktionsart zu ordnen (einfache, doppelte, gefaltete, gefaltete mit eingelegtem Gürtel); vgl. Schnack 1998, 46). Wegen der geringen Anzahl der Funde und ihrer beträchtlichen Fragmentarität ist diese Vorgehensweise in tschechischem Umfeld allerdings nicht anwendbar. Als einziger möglicher Ansatz erscheint somit eine Unterteilung in Gruppen nach Verzierungart. Unterschieden wurden insgesamt fünf Grundverzierungsgruppen, von denen mit ausgestanzten Lochlinien verzierte Gürtel am häufigsten vertreten sind. Zu weiteren festgestellten Verzierungsarten zählen Metallapplikationen, Steppen, Färben und Prägungen (Stanzen). Die Breite der erhaltenen Gürtel oszillierte zwischen 10 und $47 \mathrm{~mm}$, die maximale Länge eines (unvollständigen) Exemplars betrug $700 \mathrm{~mm}$. Erwähnt werden muss auch die Tatsache, dass es auch schwierig sein kann, einen Gürtel von anderen, der Form nach ähnlichen Gegenständen zu unterscheiden, wie etwa Riemen und Schlaufgurte (z.B. von Pferdegeschirren, Gehängen für Seitenwaffen, Hundehalsbändern, Sporen, Taschen und Geldbeuteln, Messerscheiden u.ä.; Abb. 5).

Stanzen (Kat. Nr. 1-11; Taf. I bis 3) ist, wahrscheinlich in Verbindung mit Steppen (Abb. 6; vgl.. Mould-Carlisle-Cameron 2003, 3392-3397; Egan-Pritchard 2002, 38-39), in den beobachteten Fundkomplexen eindeutig die verbreitetste und am häufigsten vertretene Verzierungsform. Das Vorkommen von auf diese Art bearbeiteten Gürteln (ggf. Riemen) ist so regelmäßig, dass sie als eigenständiger, gestanzter / gesteppter Gürtel bezeichenbarer Typ klassifiziert und abgetrennt werden können. Die Art der Ausführung, d.h. das Ausstanzen von kleinen, eine Linie bildenden Löchern, war bei allen fast identisch und unterschied sich lediglich in der Gestaltung des jeweiligen Ziermotivs. Die Funde aus dem tschechischen Umfeld fallen in die Zeitspanne ab Mitte 13. bis zweite Hälfte 14. Jahrhundert und kamen in verschiedenen soziokulturellen Umgebungen vor (Stadt, Vorburgen, Bergbauareal).

Die Verzierung mit Metallapplikationen (Kat. Nr. 12-14; Taf. IV) war ein im 13. Jahrhundert aufkommender Verzierungsstil, dessen Beliebtheit im 14. Jahrhundert seinen Höhepunkt hatte. Metallapplikationen hatten eine reiche Skala an Formen, auch das verwendete Material war variabel (am häufigsten Kupfer- und Blei-Zinnlegierungen). 
Polychromie (Kat. Nr. 15; Taf. IV) ist eine sekundäre Färbung der Narbenseite. Um ein farblich unterschiedliches Aussehen zu erreichen, hat man Zinnabarit verwendet (siehe Hoch a kol. 2017, 166).

Prägen, Ritzen und Stanzen (Kat. Nr. 16, Tab. IV) des Materials mit Stanzformen (ggf. mit einem Ritzstift) kam erst im 15. Jahrhundert in großem Maßstab in Mode. Die Prägetechnik basiert auf der Arbeit mit feuchtem Leder, in das mit einem Werkzeug (Stanzform) Ziermotive gepresst wurden. Gestanzte Motive erhielten aufgrund der Verwendung einer Form ein plastisches Aussehen (Figura, im Druck).

Absteppen der Ränder (Kat. Nr. 17-18; Taf. V) ist eine einfache Technik mit Zier- und Funktionseffekt (Festigung).

Mgr. Aleš Hoch, Ph.D., Muzeum Vysočiny Jihlava, p. o., Masarykovo nám. 55, 58601 Jihlava, Česká republika,hoch@muzeum.ji.cz 